\title{
DOCK1 wt Allele
}

National Cancer Institute

\section{Source}

National Cancer Institute. DOCK1 wt Allele. NCI Thesaurus. Code C52071.

Human DOCK1 wild-type allele is located within 10q26.13-q26.3 and is approximately 557 $\mathrm{kb}$ in length. This allele, which encodes dedicator of cytokinesis protein 1, plays a role in cytoskeletal remodeling necessary for both cell motility/migration and phagocytosis of apoptotic cells. 